\title{
Histological Description of the Interaction Between Muscle Fibers and Connective Tissue of the Fascia of the Human Trapezius Muscle
}

\author{
Descripción Histológica de la Interacción entre las Fibras Musculares \\ y Tejido Conectivo de la Fascia del Músculo Trapecio Humano
}

\author{
"Rodriguez, H.; "*Espinoza-Navarro, O.; "Silva, I.; "Quiroz, P.; "Arriaza, C.; \\ "Sanchez, C.; "Vallejos, R.; "*** Castro, M. E.; *Arias, M.; "Jimenez, L. \& "Fernandez, E.
}

RODRIGUEZ, H.; ESPINOZA-NAVARRO, O.; SILVA, I.; QUIROZ, P.; ARRIAZA, C.; SANCHEZ, C.; VALLEJOS, R.; CASTRO, M. E.; ARIAS, M.; JIMENEZ, L. \& FERNANDEZ, E. Histological description of the interaction between muscle fibers and connective tissue of the fascia of the human trapezius muscle. Int. J. Morphol., 29(1):299-303, 2011.

SUMMARY: The skeletal muscle fascia corresponds to a condensation of connective tissue. Fascias are highly innervated and sensitive, and can cover non-expandable structures as well as musculature. It is suggested that fascias have a pivotal role in functions such as postural regulation, peripheral motor coordination and proprioception. Also, the presence of inflammation and microcalcification in fascia of patients with localized muscle pain has been described, suggesting a pathogenic role in pain. The aim was to describe the histological structure of the external deep fascia of the trapezius muscle, with emphasis on the content and arrangement of muscle fibers, type I collagen, and adipose tissue. Sample material was obtained from a male cadaver (60-70 years old), by dissection of the posterior cervical region of the superficial fascia of the trapezius muscle and fixed in buffered formalin. Samples were processed by routine histological techniques and embedded in paraffin, obtaining $5 \mu \mathrm{m}$-thick sections that were stained according to the van Gieson technique. The trapezius fascia is composed of type I collagen, organized into high-density collagen bundles and oriented in different directions, and by adipocytes disposed in longitudinal groups on the main axis of the fascia. Muscle fibers are organized into bundles that are inserted laterally on the thickness of the fascia. It is possible that lateral transmission of tensional forces between the fibers might be present.

KEY WORDS: Fascia; Trapezius; Human histology.

\section{INTRODUCTION}

Work-related musculoskeletal disorders (MSD) of the neck and the shoulders are a growing problem in society. Especially in the trapezius muscle, an interesting pattern of spontaneous muscle activity in the resting state or an altered state with a mental load (Taelman et al., 2010).

The exact motor innervation of the trapezius has been controversial. Attempts to resolve the innervation of the trapezius had been studied by different method (electroneurography, surgical identification, clinical and electrophysiological studies, motor action potentials and techniques of regional anaesthesia) with unclear results. All studies have shown that the spinal accessory nerve (the XIth cranial nerve pair) and branches of the cervical plexus participate in the innervation of the trapezius. However, they do not contribute in equal proportions, neither anatomically or functionally.

The nerve supply to the descending part of the muscle consists of a single fine branch of the spinal accessory nerve, whereas the transverse and ascending parts are innervated by both the spinal accessory nerve and the trapezius branches of the cervical plexus (Stecco et al., 2006). The spinal accessory nerve provides the main motor input to the trapezius muscle (Asakawa et al., 2002; Blemker et al., 2004), especially for the superior and middle sections

* Unit of Immunohistochemistry. Program of Anatomy and Developmental Biology. ICBM. Faculty of Medicine. Universidad de Chile, Santiago, Chile.

** Departamento de Biología, Universidad de Tarapacá, Arica, Chile.

**** Universidad de Playa Ancha, Valparaíso, Chile. 
RODRIGUEZ, H.; ESPINOZA-NAVARRO, O.; SILVA, I.; QUIROZ, P.; ARRIAZA, C.; SANCHEZ, C.; VALLEJOS, R.; CASTRO, M. E.; ARIAS, M.; JIMENEZ, L. \& FERNANDEZ, E. Histological description of the interaction between muscle fibers and connective tissue of the fascia of the human trapezius muscle. Int. J. Morphol., 29(1):299-303, 2011.

(Blemker et al.). The branches of the cervical plexus (Blemker et al.; Drost et al., 2003), specifically C2-C4 branches (Drost et al.), either through the trapezius muscle by nerve anastomosis behind the trapezius or directly especially in the distal portion (Blemker et al.).

This anatomical distribution can help to minimize the risk of injuring the spinal accessory nerve during neck surgery and preserve the additional innervation of the trapezius muscle granted by the rami trapezium of the cervical plexus (Taelamn et al.). The importance in oncosurgery is frequently encountered during neck surgery, and as such, is at risk of iatrogenic injury, resulting in the 'shoulder syndrome' (Bednar et al., 1995). Therefore, it is very important as they relate the different types of tissues, i. e., muscles, connective (fascia) and adipose tissues.

Fascia is a word with a latin origin meaning "band". Skeletal muscle is a complex hierarchical organization where thousands of muscle fibers produce traction and are arranged in a network of connective tissue (Blemker et al.). The skeletal muscle fascia corresponds to a condensation of connective tissue that varies widely in density, so that may be unique and well defined or may exist only as a solid collection of connective tissue. Fascias can cover nonexpandable structures as well as musculature. The deep fascia is composed mainly of collagen fibers and is usually more compact and irregular than the superficial fascia. The deep fascia contacts immediately with the muscle and sends partitions or septa of connective tissue between muscles. Towards the end of the muscle, fascias allow a strong bond with the periosteum of bones. Fascias are heavily innervated and are thus highly sensitive.

This compartmentalization of skeletal muscles can be organized into various regions: 1) the regional dense (with dense connective tissue) or areolar (with loose connective tissue) fascia; 2) the retinaculum, which corresponds to a fascia that allows the continuity of the muscle with the tendon; and 3 ) the raphe, which corresponds to a fascia connecting the right and left counterparts of a particular muscle toward the midline, and the epimysium. The epymisium is a fascia that covers the surface of a muscle and depending on the muscle it can be thin (band) or thick (opaque); both the perimysium and endomysium derive from the epymisium. The connective tissue fibers of the fascia vary from areolar to thick bands of fibrous tissue (Rosen et al., 2002).

In recent years, the study of the deep muscle fascia has regained interest because these structures are commonly involved in the pathogenesis of a variety of pathological conditions. It has been claimed that the presence of inflammation and microcalcification in various types of fascia in patients with localized muscle pain might have a critical role of fascia in the etiology of pain (Bednar et al.). It is even hypothesized that fascias are involved in several functions such as regulation of posture, muscle biomechanics, peripheral motor coordination and proprioception (Stecco et al., 2006). For some authors fascias have the ability to adapt to physiological stresses and have an active participation in manual therapies in relation to their tone, viscosity and structure.

In humans, the trapezius is a large superficial muscle that extends longitudinally from the occipital bone to the lower thoracic vertebrae and laterally to the spine of the scapula (shoulder blade). Its functions are to move the scapulae and support the arm. The trapezius is connected to the bone by a thin fibrous lamina, firmly adherent to the skin. The superficial and deep epimisya are continuous with an investing deep fascia that encircles the neck and also contains both sternocleidomastoid muscles. The superficial fascia of the back forms a layer of considerable thickness and strength, and contains a quantity of granular fat. It is continuous with the general superficial fascia.

The objective of this study is to describe the histological structure of the external deep fascia of the trapezius muscle, with main emphasis on the content and arrangement of muscle fibers, type I collagen, and adipose tissue.

\section{MATERIAL AND METHOD}

Biological material samples were obtained from an male cadaver (unidentified), 60 to 70 years old. By dissection of the posterior cervical region, a $1 \times 2 \mathrm{~cm}$ biopsy of the superficial fascia of the trapezius muscle lining was extracted and immediately fixed in buffered formalin $\mathrm{pH} 7.2$ for a period of 48 hours. Subsequently, the samples were processed by routine histological techniques: dehydration in a battery of increasing alcohol grade ethanol (from $70^{\circ}$ to $100^{\circ}$ ), clearance in xylene (I, II and III), and inclusion in paraffin (Histosec) with a melting point between 56 and $58^{\circ} \mathrm{C}$. Five$\mu \mathrm{m}$ thick sections were made in a Leitz Wetzlar microtome and mounted on previously silanized slides. Finally, we proceeded to the development of the protocol of the van Gieson staining technique, which allows a clear differentiation of muscle tissue (stained yellowish green) and the connective tissue (stained metallic red).

Microscopic examinations were performed in the Olympus CX31 Microscope trinocular with built-in digital camera (5 megapixel) using the SE Premium Software Micrometrics 2010. 
RODRIGUEZ, H.; ESPINOZA-NAVARRO, O.; SILVA, I.; QUIROZ, P.; ARRIAZA, C.; SANCHEZ, C.; VALLEJOS, R.; CASTRO, M. E.; ARIAS, M.; JIMENEZ, L. \& FERNANDEZ, E. Histological description of the interaction between muscle fibers and connective tissue of the fascia of the human trapezius muscle. Int. J. Morphol., 29(1):299-303, 2011.

\section{RESULTS}

In the Figure 1 shows the dissection of the superficial fascia of the trapezius. Note the fascia with abundant fatty tissue in continuity with the subcutaneous tissue, while on the opposite side it is continuous with the striated trapezius muscle.

In Figures 2, 3 and 4 show the Van Gieson staining of the biopsy of the external fascia of the trapezius. It can be noted, from surface to deep, the provision of irregular dense connective tissue (red) with abundant fatty tissue (cells with

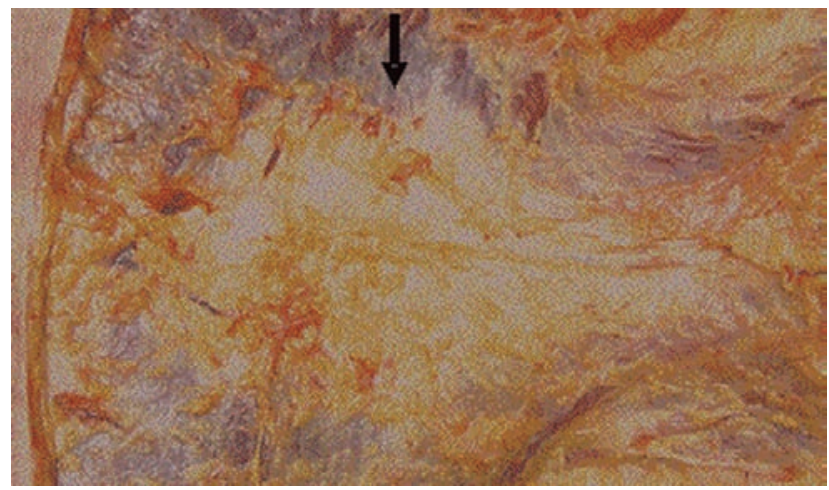

Fig. 1. Result of dissection by planes of the relationship between superficial fascia and the trapezius muscle (arrow).

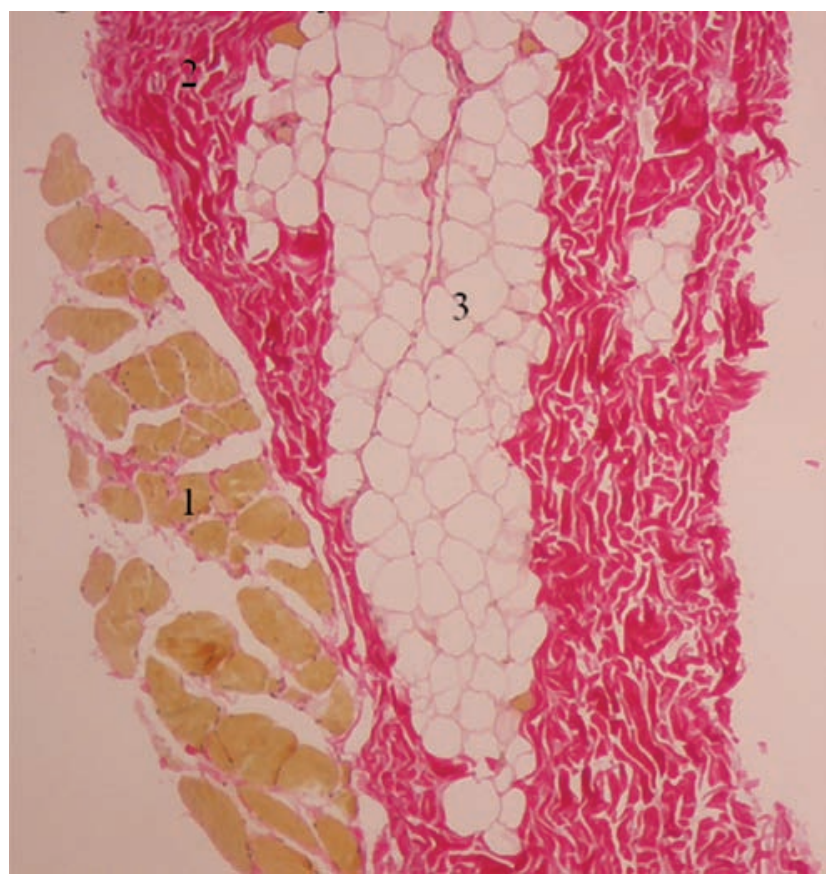

Fig. 2. Longitudinal section of the muscle fascia stained with the van Gieson technique, 10x. It highlights the skeletal striated muscle fibers (1), fibers of collagen I (2), and adipose tissue (3). Here we see the face of the fascia muscle. unstained, colorless cytoplasm); more deeply, the insertions of the striated muscle fibers (bright yellow) and the endomysium -in continuity with the fascia itself- can be noticed. Micrographs show that the striated muscle fibers are inserted laterally and at different levels into the dense connective tissue. Connective tissue also has abundant vascular irrigation.
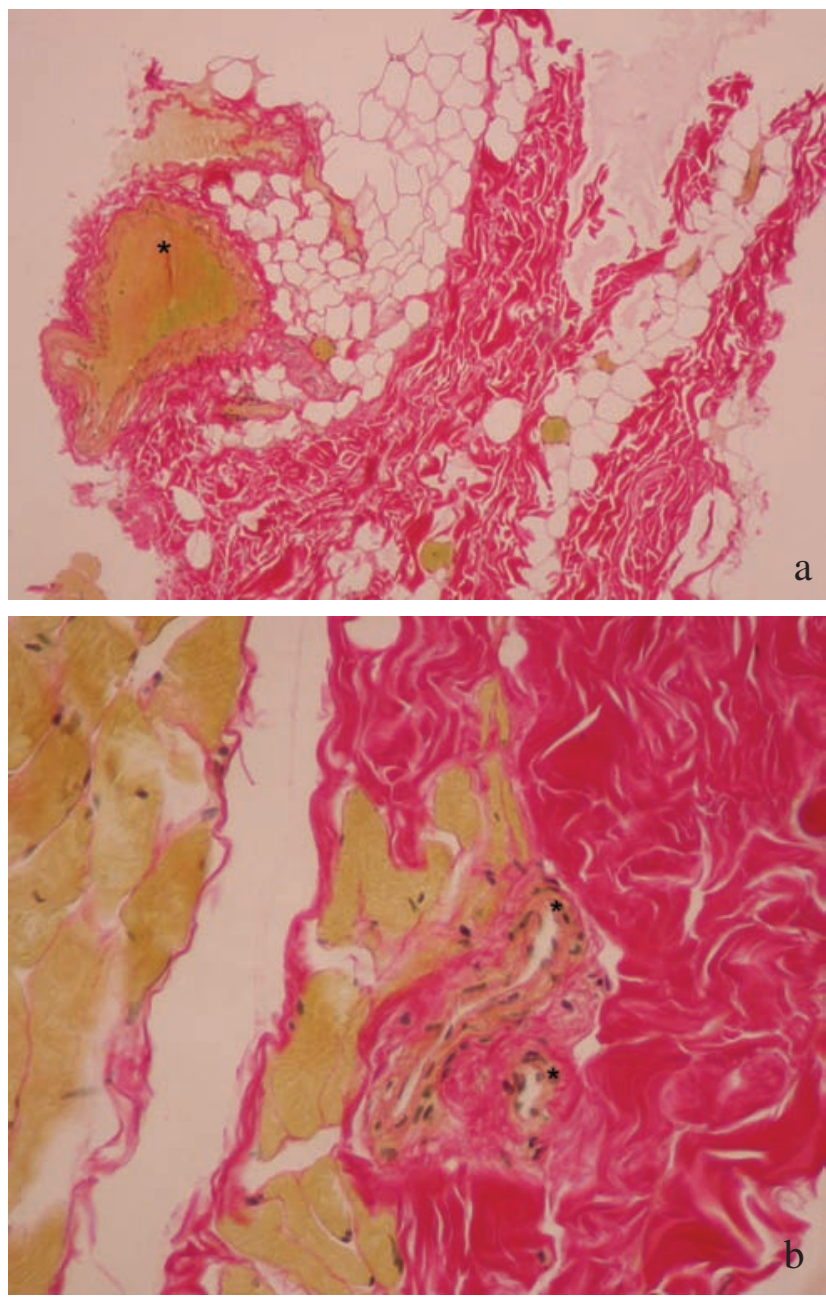

Fig. 3. Longitudinal section of the muscle fascia stained with the van Gieson technique. Figs. a and $b$ show the presence of abundant blood vessels ready to face muscular fascia (asterisk *)

\section{DISCUSSION}

The fascia has areolar connective tissue, with adipocytes arranged in longitudinal groups following the direction of the main axis of the fascia. This region is highly vascular and occupies large spaces between collagen fibers. The main histological arrangement of the fascia is organized as a dense irregular connective tissue. Type I collagen is 

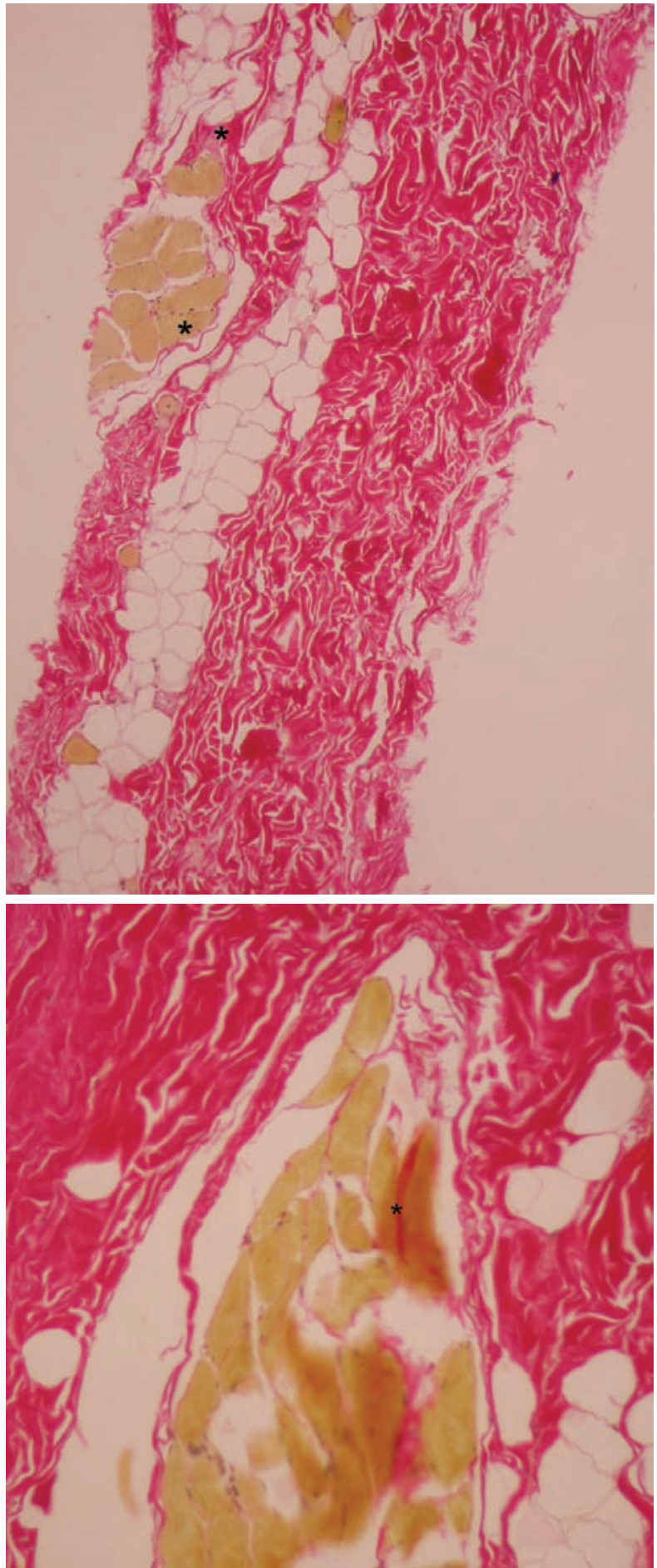

Fig. 4. Longitudinal section of the muscle fascia stained with the van Gieson technique. Figures a and b show how the skeletal striated muscle bundles are inserted into the next face of the fascia (asterisk, *).

organized in large bundles with true high-density collagen bundles oriented in different directions.
The fascia corresponds to the epimysium. Depending on the type of muscle, the fascia can be thin and transparent or thick and opaque. From the resulting fascia, connective tissue fibers form the perimysium -as an organization of dense connective tissue that envelops a group of muscle fibers- and the endomysium -which is mainly reticular connective tissue surrounding each muscle fibers involved in their relationship with the basal lamina of each of the fibers.

In recent experimental studies it has been established that the muscle bundles do not contract or shorten uniformly over the entire muscle (Ahn et al., 2003; Pappas et al., 2002; Drost et al., 2003). Dynamic magnetic resonance imaging shows that at the head of the biceps brachii, longitudinal shortening is not uniform along the fascicles during flexion (Pappas et al.). The shortening of a muscle may be affected by the difference in length between the fibers; they might be continuous with the central line of the muscle and the previous installments and/or follow the curvature of the previous installments (Asakawa et al.). The potential properties of passive stretching of the aponeurosis or fascia could also contribute to the complex distribution of forces in a muscle (Blemke et al.).

It is possible that lateral transmission of tension between the fibers might be present (Street, 1983; Trotter, 1993). This feature may play an important role in the production of forces and their transmission (Huijing, 1999; Purslow, 2002). Then, the resistance between the fibers and the preservation of muscle volume may also affect the deformation of tissues. Therefore, knowing the geometry of the muscle bundles is important to explain how a particular muscle contracts.

After detailed analysis of our captured images, it appears that muscle fibers are organized in bundles that are inserted laterally on the thickness of the fascia, and therefore does not continue in the full length of the muscle. In parallel, we observe that both the vasculature and innervation are abundant within the connective tissue.

Therefore, muscle contraction involves not only muscular tissue, but at all kinds of neighboring connective tissue components, irrigation and innervation. The existence of muscle fibers with different longitudes must also be taken into consideration. These concepts are important when diagnosing a patient with regional muscle aches and implementing a treatment including alternative therapies.

ACKNOWLEDGMENTS. The present work was partially funded by the Universidad de Tarapacá, research project $\mathrm{N}^{\circ} 4710$ 11 and FONDECYT Grant $n^{\circ} 1101046-2010$. We also appreciate the cooperation of Mr. Juan Borja as technical assistant. 
RODRIGUEZ, H.; ESPINOZA-NAVARRO, O.; SILVA, I.; QUIROZ, P.; ARRIAZA, C.; SANCHEZ, C.; VALLEJOS, R.; CASTRO, M. E.; ARIAS, M.; JIMENEZ, L. \& FERNANDEZ, E. Histological description of the interaction between muscle fibers and connective tissue of the fascia of the human trapezius muscle. Int. J. Morphol., 29(1):299-303, 2011.

RODRIGUEZ, H.; ESPINOZA-NAVARRO, O.; SILVA, I.; QUIROZ, P.; ARRIAZA, C.; SANCHEZ, C.; VALLEJOS, R.; CASTRO, M. E.; ARIAS, M.; JIMENEZ, L. \& FERNANDEZ, E. Descripción histológica de la interacción entre las fibras musculares y tejido conectivo de la fascia del músculo trapecio humano. Int. J. Morphol., 29(1):299-303, 2011.

RESUMEN: La fascia del músculo esquelético corresponde a una condensación de tejido conectivo. Las fascias están inervadas y son sensibles y pueden cubrir estructuras no distensibles, así como las fibras musculares esqueléticas. Tienen un rol importante en la regulación de la postura, la coordinación motora periférica y la propiocepción. Además, se ha descrito la presencia de inflamación y microcalcificaciones en la fascia de los pacientes con dolor muscular localizado, lo que sugiere un rol patogénico en el dolor. El objetivo del trabajo fue describir la estructura histológica de la fascia externa profunda del músculo trapecio, con énfasis en el contenido y la disposición de las fibras musculares, colágeno tipo I y el tejido adiposo. Material y métodos: El material de la muestra fue obtenido de un cadáver de sexo masculino (60-70 años), por la disección de la región cervical posterior de la fascia superficial del músculo trapecio e inmediatamente fijado en formalina tamponada ( $\mathrm{pH} \mathrm{7,2)} \mathrm{durante} 48$ horas. La muestra fue procesada por técnicas histológicas e impregnada en parafina (punto de fusión $56-58^{\circ} \mathrm{C}$ ). Secciones de $5 \mu \mathrm{m}$ de espesor fueron montadas en láminas silanizada para el desarrollo del protocolo de la técnica de van Gieson. Resultados y discusión: Se observa que la fascia del trapecio está compuesta por tejido conectivo denso irregular con abundante colágeno tipo I, organizado en paquetes grandes como verdaderos haces de colágeno de alta densidad orientada en diferentes direcciones; y por adipocitos dispuestos en grupos longitudinales en el eje principal de la fascia. Las fibras musculares estriadas están organizadas en paquetes que se insertan lateralmente en el espesor de la fascia. Es posible que la transmisión lateral de la tensión entre las fibras esté presente.

PALABRAS CLAVE: Fascia; Trapezius; Histología humana.

\section{REFERENCES}

Ahn, A; Monti, R \& Biewener, A. A. In vivo and in vitro heterogeneity of segment length changes in the semimembranosus muscle of the toad. J. Physiol., 549:87788,2003

Asakawa, D; Pappas, G; Delp, S. \& Drace, E. Aponeurosis length and fascicle insertion angles of the biceps brachii. J. Mechan. Med. Biol., 2:449-55, 2002.

Bednar, A; Orr, W. \& Simon, T. Observations on the pathomorphology of the thoracolumbar fascia in chronic mechanical back pain. Spine, 20:1161-4, 1995.

Blemker, S; Pinskya, P. \& Delpa, S. A 3D model of muscle reveals the causes of nonuniform strains in the biceps brachii. $J$. Biomech., 38:657-65, 2004.

Drost, R; Maenhout, M.; Willems, J.; Oomens, W.; Baaijens, P. \& Hesselink, K. Spatial and temporal heterogeneity of superficial muscle strain during in situ fixed-end contractions. J. Biomech., 36:1055-63, 2003.

Huijing, P. Muscle as a collagen fiber reinforced composite: a review of force transmission in muscle and whole limb. $J$. Biomec., 32:329-45, 1999.

Pappas, P.; Asakawa, S.; Delp, L.; Zajac, E. \& Drace, E. Nonuniform shortening in the biceps brachii during elbow flexion. J. Appl. Physiol., 92:2381-9, 2002.

Purslow, P. The structure and functional significance of variations in the connective tissue within muscle. Comp. Biochem. Physiol. A Mol. Integr. Physiol., 133:947-66, 2002.
Rosen, E; Bailey, B; Quinn, F \& Ryan, M. Deep neck spaces and infections. Avalaible in: http://www.utmb.edu/otoref/Grnds/ Deep-Neck-Spaces-2002-04/Deep-neck-spaces-2002-04.pdf, 2002.

Stecco, C.; Porzionato, A.; Macchi, V.; Tiengo, C.; Parenti, A.; Aldegheri, R.; Delmas, V. \& De Caro, R. Histological study of the deep fascia of the upper limb. Ital. J. Anat. Embryol., 111:105-10, 2006.

Street, F. Lateral transmission of tension in frog myofibers: a myofibrillar network and transverse cytoskeletal connections are possible transmitters. J. Cell Physiol., 114:346-64, 1983.

Taelamn, J.; Deburchgraeve, W.; van Damme, K.; Adriaensen, T.; Spaepen, A. \& van Huffel, S. Detection algorithm for single motor unit firing in surface emg of the trapezius muscle. Method Inf. Med., 49:492-5, 2010.

Trotter, A. Functional morphology of force transmission in skeletal muscle. A brief review. Acta Anat. (Basel), 146:205-22, 1993.

Correspondence to:

Prof. Dr. Héctor Rodriguez.

Anatomy and Developmental Biology.

Faculty of Medicine. Universidad de Chile.

PO Box 70079. Santiago-7.

Av. Independencia 1027.

Santiago - CHILE

Email: hrodrigu@med.uchile.cl

Received: 26-10-2010

Accepted: 28-11-2010 